\title{
An Investigation into the Effect of Small and Medium Enterprises (SMEs) on the Socio-Economic Development of Alice in Eastern Cape Province, South Africa
}

\author{
Akeem Adewale Oyelana* \\ Department of Business Management, University of Fort Hare, Alice, \\ P.B. X1314, Eastern Cape, 5700, South Africa. \\ Email:201100592@ufh.ac.za \\ Gebregziabher Gebreyesus Fiseha \\ Department of Development Studies, University of Fort Hare, Alice, \\ P.B. X1314, Eastern Cape, 5700, South Africa \\ 201105862@ufh.ac.za
}

Doi:10.5901/mjss.2014.v5n23p674

Abstract

Nowadays, economists' believe that Small and Medium Enterprises (SMEs) played an important role in improving socioeconomic development of a nation. Hence, for more jobs to be created, poverty to be alleviated, there is a need for the government to encourage more SMEs establishment in the country. This study investigated the effect of SMEs in the socioeconomic development of Alice in terms of poverty alleviation, reduction of unemployment and crime. The objective of this study was to assess the role of SMEs in the socio-economic development of Alice. Data was collected through selfadministered questionnaires and the use of random sampling. Quantitative data was analysed using descriptive and inferential statistics of Chi-square as the statistical tool. The findings of this study suggest that SMEs are not playing a substantial role in addressing the challenges related to high unemployment, crime, and poverty reduction. SMEs are neither enhancing living standards nor stimulating economic growth and development in Alice due to a number of challenges, namely lack of finance, lack of managerial skills, inadequate advice and information, and lack of training and education. The study recommended that to increase the contribution of SMEs in the socio-economic problems of Alice, it is important to have a clear policy and strategy towards the development of SMEs and would also require commitment from government, civil society and business people.

Keywords: Strategies, Small and Medium Enterprises, Socio-Economic, Development, Eastern, Cape, South Africa

\section{Introduction}

Although the main aim of any business is to generate a profit, there are other secondary aims of which socio-economic development forms a part. Small and Medium Enterprises (SMEs) are valuable in the promotion of entrepreneurship, providing job opportunities, creating new jobs, the alleviation of poverty and fostering economic welfare (Kroon, 2000:27). Throughout the world, Small and Medium Enterprises are playing a crucial role in socio-economic development in various ways: by creating employment for the urban and rural labour force, poverty reduction, promoting health, stimulating economic growth and equity, as well as increasing the living standard of the people, especially through enhancement of innovation in the economy as a whole (Kroon, 2000:29). According to the United States of America Small Businesses Administration, (2006:1) report shown that SMEs represent over ninety nine percent (99\%) of the total number of United States of America businesses and employ over fifty percent (50\%) of the country's labour force. Since 1994 the new democratic South Africa still faces enormous social and economic challenges, such as high unemployment, crime, poverty, income inequality, HIVI AIDS and shortage of housing. The high degree of unemployment and poverty with their resultant high crime rate has become one of the most prominent issues of concern in South Africa (Snower \& De La Dehesa, 1997:1).

According to the Statistics of South Africa, (2010) report revealed that the official unemployment rate in South Africa is twenty five percent (25\%), and mainly is responsible for poverty, crime and income inequality. Small and Medium Enterprises are therefore expected to be an important vehicle in addressing the challenges of poverty reduction, income inequality, crime, HIV as well as unemployment in South Africa. Finally, Small and Medium Enterprises (SMEs) are considered to be the backbone of virtually all economies around the world. In South Africa, an SME is described as a 
registered company with a maximum of two hundred (200) employees and an annual turnover in sales of a maximum of five (5) million Rand. It was found that there are an estimated eight hundred thousand (800 000) SMEs in South Africa, absorbing about a quarter of the labour force of fifteen (15) million and about three point five (3.5) million people are involved in this sector (Department of Trade and Industry, 1995). Zindiye, (2008:1) agrees that the promotion of Small and Medium Enterprises (SMEs) is widely recognised in developing countries as a key strategy for economic growth, job creation and poverty alleviation, and yet their full potential remains untapped. SMEs represent over ninety percent (90\%) of African business operations and contribute to over fifty percent (50\%) of African employment and the gross domestic product (GDP) of the country (Central Statics Service, 2002). In short, the ability of Smaller Enterprises to generate jobs is clearly recognised by many governments. This is very significant in order for social and economic objectives to be realised.

According to Onugu, (2005:15) Small and Medium Enterprises (SMEs) occupy a place of pride in virtually every country or state. Because of their significant roles in the development and growth of various economies, they have aptly been referred to as "the engine of growth" and "catalysts for socio-economic transformation of any country." SMEs represent a veritable vehicle for the achievement of national economic objectives of employment generation and poverty reduction at low investment cost as well as the development of entrepreneurial capabilities. Furthermore, Onugu, $(2005: 15)$ states that the existence of SMEs brings stimulation of economic activities such as them being suppliers of various items and distributive trades for items produced and or needed by the community. SMEs also are vehicles for the enhancement of the standard of living of the employees and their dependents, as well as those who are directly or indirectly associated with them. Glen, (2000:373) on the other hand, maintains that in a community where several SMEs are located, it is clear that SMEs have a big interest in the development of such community.

\section{Challenges Experienced by SMEs in Enhancing Socio-Economic growth and Development in South Africa}

This section discussed on the challenges faced by SMEs in South Africa. It is clear from the literature that there are many different factors hampering the success of small businesses in South Africa. They are constrained by financial as well as non-financial issues (lack of education, poor to access to market, lack of information, inadequate technical skills and lack of infrastructure). Although, SMEs have the potential to create jobs and accelerate economic growth in South Africa, they are still faced with a large number of constraints and limitations. The objective of this section is to analyse the challenges experienced by SMEs in enhancing socio-economic growth and development in South Africa.

Many governments around the world provide a variety of initiatives to assist Small and Medium Enterprises to increase their contribution towards socio-economic development. In both developed and developing countries, the SME sector is widely recognised as a vehicle for economic growth, poverty alleviation, job creation and income generation (Sunter, 2000:23). In South Africa, the development of SMEs also plays a crucial role in improving welfare, employment creation and alleviating poverty (Riley, 1996:11). However, compared to large enterprises in South Africa and other countries, SMEs face a large number of constraints and problems and are less able to address their problems. The constraints relate to the legal and regulatory environment and they are the main handicap of the success of SMEs. Ferreira, (2007:61) argues that there are many barriers to the development and growth of SMEs. Some of these barriers include: lack of market access, lack of competent advice, Insufficient demand for products or services, High tax rates and business regulations, Cash-flow problems, Lack of knowledge resources, Inadequate infrastructure, High crime rate, Corruption, Lack of proper business strategy and planning. In addition, small businesses still face numerous challenges and constraints. These constraints prohibited SMEs from executing their responsibilities of job creation, poverty alleviation and sites of innovations. These constraints include the lack of finance, poor management capabilities, high crime rates, lack of access to information sources, lack of technology support and marketing (Zwane, 2009:28). All these and others are the main handicap to the success of SMEs, particularly in their early growth stages. Sinxoto, (2007:41) argues that less than half of new established small businesses survive beyond five years. Furthermore, Ligthelm and Cant, (2002:1) argue that the estimated failure rate of SMEs is between seventy percent (70\%) and eighty percent (80\%) due to lack of experience to operate a business. Therefore, SME managers/ owners must be trained and assisted to acquire the needed skills, particularly management skills, to enhance the success rate of SMEs in South Africa, in order to be able to assist in the alleviation of poverty and the unemployment rate.

Ligthelm and Cant, (2002:121), state that SMEs face numerous challenges which affect their development and growth. Some of these challenges are stated clearly and are discussed below, which are: 


\subsection{Access to finance}

Lack of access to capital is the primary reason for SME failure and it is considered to be the greatest problem facing small businesses. Nieuwenhuizen and Groenewald, (2004:29) argue that small business development is always constrained by the limited availability of financial resources to obtain additional inflows of capital to support expansion and growth. These difficulties create barriers to SME success. The majority of SMEs do not have access to finance in order to increase their contribution towards socio-economic development. In South Africa, most SMEs are relying solely on personal resources or money, from families and friends during the start-up, as well as during the growth phase of the business (Nieman, 2006:256). Because SMEs do not have enough security to provide banks in exchange for loans, therefore, the role of finance has been recognised as a key factor for the success of SMEs to enhance their contribution in the alleviation of poverty and job creation.

\subsection{Marketing access}

In South Africa, the role of SMEs to drive wealth creation, poverty alleviation and economic empowerment is widely recognised by national, provincial and local governments (Petrus, 2009:1). However, marketing is one of the most important factors hampering the success of SMEs in South Africa, and marketing consists of different marketing activities, such as sales, increasing the market share, to the introducing of particular new products or building relationships with customers. Marketing of an SME determines in the long term whether the business has the potential to succeed or not. Market-based growth has been realised as a very important engine to reduce poverty and job creation. Access to a market helps to develop actual abilities in the market place of an SME, by increasing innovation ideas, which bring about price reductions and help create a customer-oriented approach. Nieman, (2006:28) believes that marketing skills help owners/ managers to know how to find interested customers and how to present the product in a manner attractive to buyers. Access to both domestic and foreign markets, remains a significant constraint facing the small-scale entrepreneur.

Jones and Tilley, (2003:8) mention that lack of sufficient capital and skills are the most important constraints small local businesses experience, hampering expansion into the export market. As a result, small businesses face a high marketing risk due to limited product range (Naude \& Havenga, 2004:112). Most small businesses produce one kind of goods or service only or at least a very limited range of them. This exposes them to problems, should consumer preference and demand conditions change. Furthermore, Naude and Havenga, (2004:112) concluded that due to lack of competency, financial resources and limited time, small businesses are often not able to identify and pursue new international market opportunities.

\subsection{Regulations and rules}

Ferreira, (2007:50) argues that Small and Medium Enterprises in South Africa are not performing up to their expectation to solve the unemployment problem, due to a number of constraints, such as bureaucratic rules, regulations and tax. Furthermore, Petrus, (2009:26) believes that the tax system is not conducive for the development of SMEs and has a detrimental effect on their opportunities to increase their contribution towards socio-economic development. The degree and difficulty of tax legislation and subsequent paperwork, is among the major handicaps in the development of Small and Medium Enterprises in South Africa. Tax implications have the ability to increase the costs of doing business and usually impose large costs on society as a whole. Zwane, (2009:12) believes that the cost of doing business within the South African economy, is the highest in the world.

\subsection{Lack of access to technology and information}

Information and communication technology is a very important tool to expand economic opportunity by enabling people to enhance their knowledge and skills, identify, apply, and qualify for better-paying jobs. It would also be beneficial if they could use their disposable income more wisely, manage their own businesses efficiently as well as to offer a variety of products and services to consumers and other businesses. Many Small enterprises in South Africa have lack of time, resources, technology or expertise to research and develop new business ideas and innovation (Jones \& Tilley, 2003: 8). These barriers can become a decisive factor limiting development and expansion of small enterprises in enhancing socioeconomic development. Small businesses should use their internet networks to gain access to the latest technology or innovations pertinent for their venture to operate in. 


\subsection{Education and management training}

Different researchers indicate that in developed countries, entrepreneurship education and training at school level play a significant role in the contribution to socio-economic development. According to the National Small Businesses Strategy (1996), the acquisition of relevant vocational, technical and business skills is generally considered as one of the most important factors for success in small businesses. Furthermore, experts in the field of entrepreneurship believe that the contribution of small businesses to the socio-economic growth of the country can be much higher if entrepreneurship education and training is implemented at school levels. In South Africa, many entrepreneurs in the SME sector characterised low priority to training and education due to poorly trained educators and lack of adequate resources. Business owners/ managers lack technical skills such as designing and to produce quality products, but also expertise in implementing growth strategies for their enterprises.

Most of the SME owners/ managers in South Africa lack educational background, particularly among the households, the young as well as among the previous disadvantaged people (Petrus, 2009:19). Therefore, to enhance the success of small business, the South African government and other role players should have to commit themselves to provide effective entrepreneurial education and relevant training to facilitating managerial skills. Nieman, (2006:150) states that training is a critical source for any employee; it offers them with information, expertise and capabilities to execute their job properly. Small businesses have a valuable contribution to the socio-economic development sector by supplying experienced talent.

\subsection{Managerial skill}

In South Africa, the role of Small and Medium Enterprises in their efforts of job creation, poverty alleviation, economic growth, innovation, income generation and promotion of enterprise has been widely realized. While SMEs are important in terms of their overall share of GDP, it is also clear that many SMEs have lack of both managerial and technical skills, which hamper their success. Nieman, Hough and Nieuwenhuizen, (2003:14) conclude that there is generally a deficiency of management and leadership in many small businesses. Many small businesses in South Africa experience a lack of managerial skills, such as financial, marketing and human managerial skills in order to operate their businesses successfully in achieving socio-economic development. Therefore, the challenge of managerial skill can become the decisive factor that affects the development of SMEs in South Africa imperative to increase their contribution in the socioeconomic problems.

\subsection{Crime rate}

Given the importance of SME as a driver of economic growth and job creation, particularly in South Africa, the extent to which crime is damaging the success of small businesses tremendous. Crime is one of the major constraints to doing business in South Africa and thus affects SMEs quite severely. According to the World Bank Report (2005), it is revealed that crime is one of the four major constraints to the success of many SMEs in South Africa. Crime has a substantial impact on SME and the communities. It can affect a small businesses ability to attract customers, recruit and retain employees, lower workplace morale as well as the productivity of its employees.

\subsection{Access to advice and information}

The South African government has been playing a significant role in the success of many Small and Medium Enterprises. By provision of advice and dissemination of information to SMEs it is possible to create more jobs and reduce poverty. A large number of institutions were established by the Small Business Development Policy to help small businesses to increase their contribution towards to the socio-economic factors, such as unemployment and poverty. Khula Enterprise Promotion Agency was formed in 1996 to provide loans and guarantees to small businesses in order to increase their access to finance through commercial banks as well as SEDA (Small Enterprises Development Association) which was established in 1996 through the Department of Trade Industry (DTI) to provide non-financial support to SMEs (Zwane, 2009:15). Although many different institutions and programmes are established to support the development and growth of small businesses in South Africa, a number of small businesses still face many challenges (Ferreira, 2007:129). Because of that fact that the number of institutions effectively reached, remains small, compared to the vast number of people involved in self-employment in both urban and rural areas. Furthermore, it is believed that the government's efforts to enhance small businesses in South Africa should ensure that the socio-economic factors, such as high unemployment 
and poverty in South Africa are addressed. A large number of these and others barriers have prohibited small businesses from executing their responsibilities as catalysts of job creation, poverty alleviation and economic growth in South Africa (Zwane, 2009:2). Finally, to enhance the success rate of SMEs in South Africa for the alleviation of poverty and job creation, the government and other role players should be committed to create a proper legal environment for entrepreneurs.

\section{Research Methodology}

The study used the quantitative research design and survey research method of data collection. The study involved 27 SMEs in Alice in the Eastern Cape Province of South Africa. Data for the research study was collected through selfadministered questionnaires and the use of random sampling. Questions related to an investigation into the effect of SMEs on Socio-Economic Development are usually insightful. Responsive questions such as the names and contact addresses of the respondents were removed from the questionnaire. The questionnaire consisted of primarily five-point Likert scale questions which consist of 1=strongly disagree, 2=disagree, 3=undecided, 4=agree and 5=strongly agree questions except for demographic questions. Data analysis included using Chi-square goodness of fit test and descriptive statistics as the statistical tool. The empirical research for the study was conducted in the main survey.

\section{Results}

Unemployment, poverty, income inequality among others, are the most severe problems in South Africa and are conceivably the root cause of numerous other economic and social problems such as crime and violence. Changing economic and social conditions are affecting an increasing number of people into the growing business sector from the self-employed individual to the entrepreneur who commences a small business enterprise employing staff to attempt to increase their operational levels. Although SMEs are the main contributors to the South African economy and are regarded as the main driving force to the challenges of unemployment reduction, poverty alleviation, and crime reduction and to enhance the living standard, in the context of Alice, SMEs are not playing a crucial role towards the socioeconomic development of Alice. As a result of this, Alice faces so many socio-economic problems, such as high unemployment rate, crime rate, poverty, HIVI AIDS and income inequality. Therefore, in order to increase the contribution of SMEs towards the socio-economic problems of Alice, the government and other role players should create a proper legal environment for Individual entrepreneurs and groups of small businesses.

\section{Data Analysis, Presentation and Interpretation}

The gender information is vital in order to enable the researcher to obtain information on whether the respondents are males or females.

Table 1: Gender of respondents

\begin{tabular}{|cc|c|c|c|c|}
\hline & Frequency & Percent & Valid Percent & Cumulative Percent \\
\hline \multirow{4}{*}{ Valid } & Male & 20 & 74 & 74 & 74 \\
& Female & 7 & 26 & 26 & 100.0 \\
& Total & 27 & 100.0 & 100.0 & \\
\hline
\end{tabular}

Source: Survey data (2011)

Table 1 showed that, in the sample of 27 respondents, 20 were males, representing $74.0 \%$ whereas females accounted for $26.0 \%$. This result indicates that men are more actively engaged in the entrepreneurial ventures than women in the survey area.

This information is important to obtain information on whether the respondents are young or old. 
Figure 1: Age of respondents

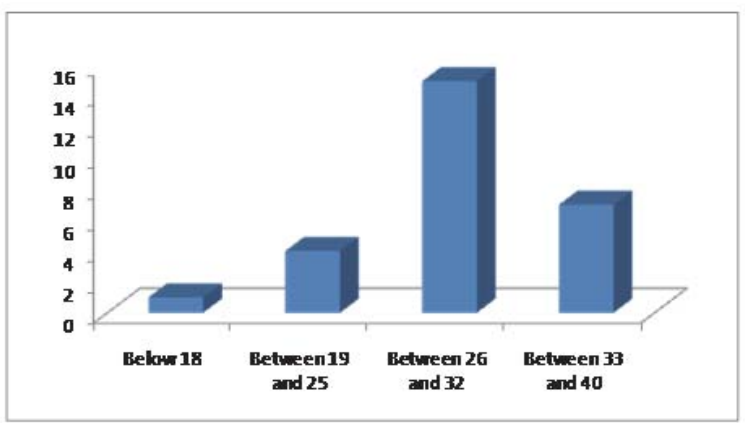

Source: Survey data (2011)

Figure 1 showed that most of the respondents were aged between 26 and 32 years, followed by those aged between 33 and 40. Only one respondent was aged below 18 years. The result indicates that most of the people involved in SMEs are between the ages of 26 and 32 and could be seen as experienced business people.

This information below identify whether the respondents are managers or owners or both in the business.

Table 2: Position/ role in business

\begin{tabular}{|c|c|c|c|c|c|}
\hline & & Frequency & Percent & Valid Percent & Cumulative Percent \\
\hline \multirow{5}{*}{ Valid } & Missing & 1 & 4 & 4 & 4 \\
\hline & Owner & 7 & 26 & 26 & 30 \\
\hline & Manager & 16 & 59 & 59 & 89 \\
\hline & Both & 3 & 11 & 11 & 100.0 \\
\hline & Total & 27 & 100.0 & 100.0 & \\
\hline
\end{tabular}

Source: Survey data (2011)

It is illustrated in table 2 that the majority of respondents were managers who represented $59.0 \%$, followed by owners of the business entities accounting for $26.0 \%$ and those who were both managers and owners (11.0\%). One respondent (4.0\%) did not indicate his/ her position in the business. These results show that the majority of respondents do not own the business.

The figure below illustrates the information on educational level of respondents.

Figure 2: Educational Qualification of Respondents

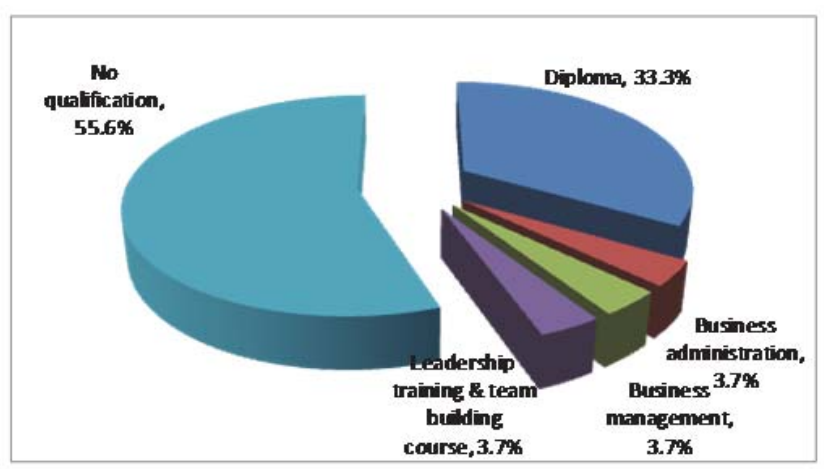

Source: Survey data (2011)

Figure 2 indicates that, out of 12 respondents who indicated having a business related qualification, 9 (33\%) had a Diploma, 1 each (4\%) had qualifications on Business administration, Business management and Leadership Training and 
the magority (55\%) did not have formal qualifications, indicating a very low level of qualified business people.

Below information is essential in order to obtain information on whether the business of the respondents is classified as a sole proprietorship, partnership, close corporation or family business.

Figure 3: Nature of the organization

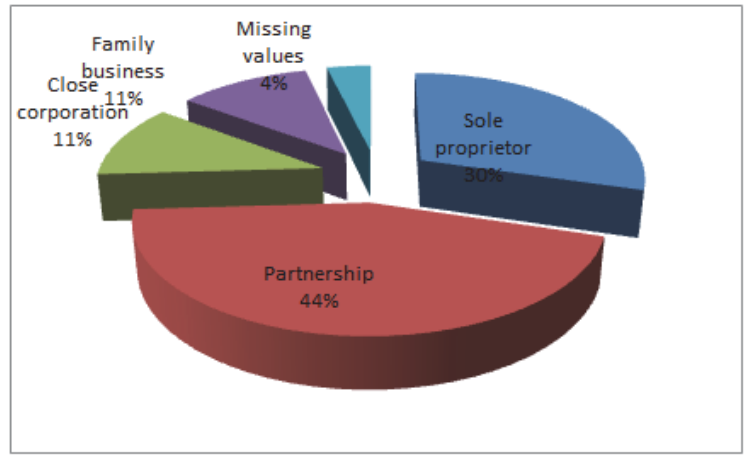

Source: Survey data (2011)

Figure 3 shows that the sample studied was dominated by partnerships (44.0\%) followed by sole proprietor (30.0\%), family business (11.0\%) and close corporation (11.0\%). Four respondents (4.0\%) did not provide an answer to this question. Results indicated that individuals had to pool their money in order to be able to do business.

This information helps the researcher to obtain information on how long the business of the respondent has been in operation.

Table 3: Duration of the business

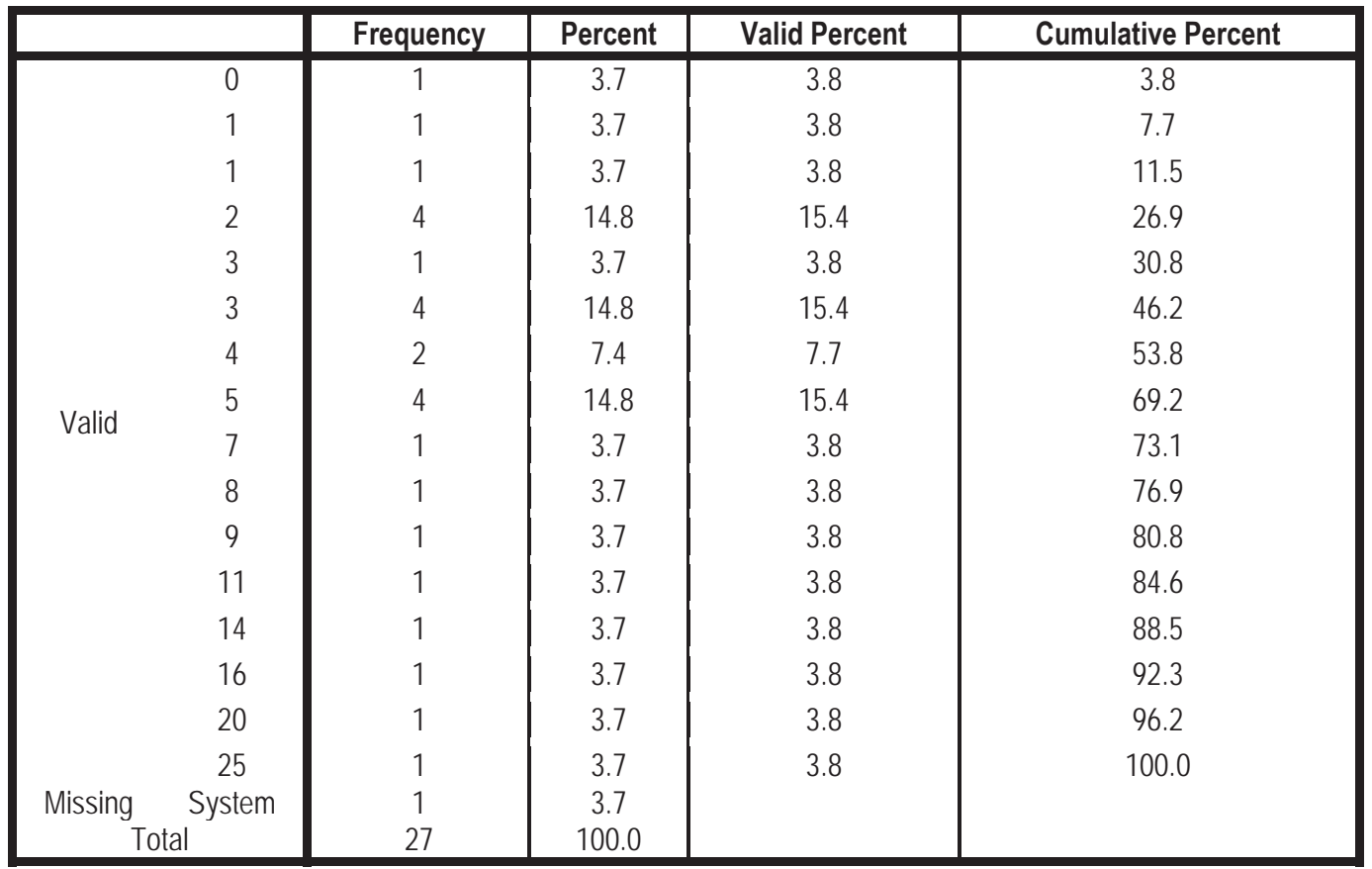

Source: Survey data (2011)

Table 3 indicates that the majority (30\%) of the respondents have been operating their business for more than seven years. Approximately fifteen percent (15\%) of the business of respondents have been in operation from two up to five years. The remainder, which amounts to seven point four percent (7.4\%), have been in operation for more than one year. One (3.7\%) respondents business has been operating for a period shorter than one year and three point seven percent 
(3.7\%) of respondents did not answer this question. Results indicate that SMEs in Alice are in operation beyond the 5 years required for their start-up.

Table 4: Number of employees at the starting of the business

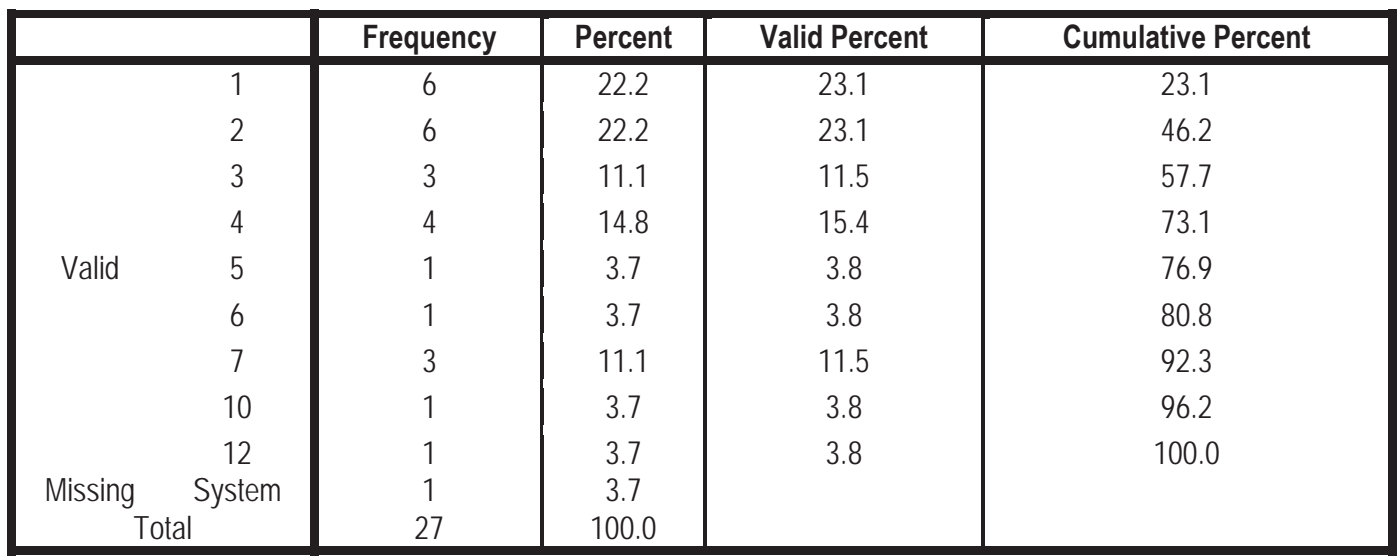

Source: Survey data (2011)

Table 4 indicates that regarding employment, most of the business entities had started with an employment size of between 1 and 4 people (70.3\%). One establishment had started with as many as 12 employees (3.7\%). One respondent (3.7\%) did not provide an answer to this question.

This information below examines the number of employees available currently in the same business as above.

Table 5: Number of employees in the business at the moment

\begin{tabular}{|c|c|c|c|c|}
\hline & Frequency & Percent & Valid Percent & Cumulative Percent \\
\hline \multirow{10}{*}{ Valid } & 3 & 11.1 & 11.5 & 11.5 \\
\hline & 5 & 18.5 & 19.2 & 30.8 \\
\hline & 3 & 11.1 & 11.5 & 42.3 \\
\hline & 3 & 11.1 & 11.5 & 53.8 \\
\hline & 3 & 11.1 & 11.5 & 65.4 \\
\hline & 1 & 3.7 & 3.8 & 69.2 \\
\hline & 3 & 11.1 & 11.5 & 80.8 \\
\hline & 1 & 3.7 & 3.8 & 84.6 \\
\hline & 2 & 7.4 & 7.7 & 92.3 \\
\hline & 1 & 3.7 & 3.8 & 96.2 \\
\hline 21 & 1 & 3.7 & 3.8 & 100.0 \\
\hline Missing System & 1 & 3.7 & & \\
\hline Total & 27 & 100.0 & & \\
\hline
\end{tabular}

Source: Survey data (2011)

Table 5 indicates that most business entities have an employment size of between 1 and 5 . Approximately (26\%) business entities have an employment size between 6 and 12, whilst seven point four (7.4\%) SMEs employed within the range of 18-21 employees. One respondent (3.7\%) did not provide an answer to the question. This result indicates that most of SMEs employ a small number of employees, because they are constrained by a lack of finance as well as market access and lack of support institutions in order to grow and expand their business, which could assist in the alleviation of socio-economic problems of Alice. It also shows that almost all entities employ more people than at their start-up stage, indicating that they actually attempt to create employment for the people of their choice.

Below information identify whether SMEs contribute to achieving economic growth in the study area. 
Table 6: The role of SMEs in achieving economic growth

\begin{tabular}{|cc|c|c|c|c|}
\hline & & Frequency & Percent & Valid Percent & Cumulative Percent \\
\hline \multirow{4}{*}{ Valid } & Strongly agree & 10 & 37.0 & 38.5 & 38.5 \\
& Agree & 12 & 44.4 & 46.2 & 84.6 \\
& Neutral & 3 & 11.1 & 11.5 & 96.2 \\
\multirow{2}{*}{ Missing } & Disagree & 1 & 3.7 & 3.8 & 100.0 \\
& System & 1 & 3.7 & & \\
& Total & 27 & 100.0 & & \\
\hline
\end{tabular}

Source: Survey data (2011)

Results in table 6 indicates that the majority of respondents supported the assertion that their businesses had played a significant role in achieving economic growth in the study area (81.4\%) and only one (3.7\%) disagreed. Three respondents (11.1\%) were indifferent, and one respondent (3.7\%) did not provide a response to this question. This result indicates that SMEs owners/ managers believe that they are playing a significant role in achieving economic growth.

Figure 4: The role of SMEs in reducing unemployment

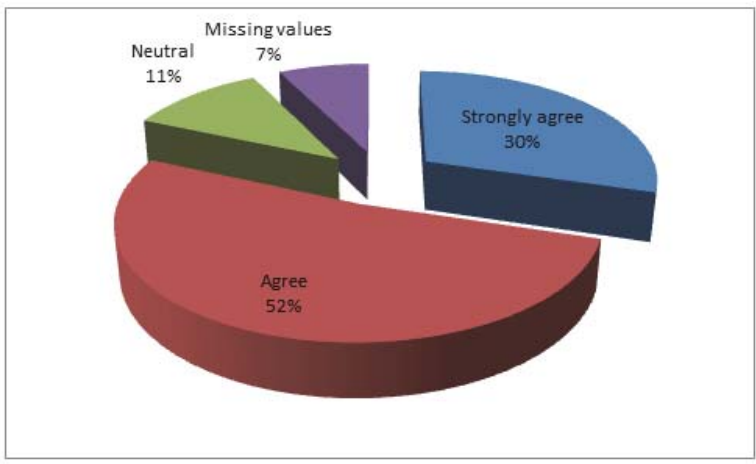

Source: Survey data (2011)

Figure 4 illustrates the important role of businesses in reducing the unemployment rate in the study area, and $82 \%$ agreed, while $11 \%$ remained neutral. Two respondents (7\%) did not provide an answer to this question. This result proves that SMEs play an important role in attempting to provide employment opportunities, and thus could contribute to poverty alleviation.

Responses below determine whether SMEs contribute towards poverty alleviation.

Table 7: The role of SMEs in reducing poverty

\begin{tabular}{|cc|c|c|c|c|}
\hline & & Frequency & Percent & Valid Percent & Cumulative Percent \\
\hline \multirow{4}{*}{ Valid } & Strongly agree & 7 & 25.9 & 29.2 & 29.2 \\
& Agree & 13 & 48.1 & 54.2 & 83.3 \\
& Neutral & 2 & 7.4 & 8.3 & 91.7 \\
& Disagree & 1 & 3.7 & 4.2 & 95.8 \\
\multirow{4}{*}{ Missing } & Strongly disagree & 1 & 3.7 & 4.2 & 100.0 \\
& System & 3 & 11.1 & & \\
& Total & 27 & 100.0 & & \\
\hline
\end{tabular}

Source: Survey data (2011)

In table 7, the majority of respondents supported the assertion that their businesses had played a significant role in reducing poverty in the study area (74.0\%), only two (7.4\%) disagreed. Two respondents (7.4\%) were indifferent, and 
three respondents (11.1\%) did not answer this question. The result indicates that most SMEs are attempting to assist indigenous people by selling certain goods at a cheaper price to reduce poverty in the area.

This information below enables the researcher to determine whether SMEs contribute to the crime reduction in Alice.

Table 8: The role of SMEs in reducing crime

\begin{tabular}{|cc|c|c|c|c|}
\hline & & Frequency & Percent & Valid Percent & Cumulative Percent \\
\hline \multirow{4}{*}{ Valid } & Strongly agree & 2 & 7.4 & 8.7 & 8.7 \\
& Agree & 10 & 37.0 & 43.5 & 52.2 \\
& Neutral & 5 & 18.5 & 21.7 & 73.9 \\
& Disagree & 2 & 7.4 & 8.7 & 82.6 \\
\multirow{4}{*}{ Missing } & Strongly disagree & 4 & 14.8 & 17.4 & 100.0 \\
& System & 4 & 14.8 & & \\
& Total & 27 & 100.0 & & \\
\hline
\end{tabular}

Source: Survey data (2011)

Table 8 indicates about businesses playing a significant role in reducing crime in the study area. It showed that $44.4 \%$ of respondents agreed, while $22.2 \%$ disagreed. Five respondents (18.5\%) were indifferent and $14.8 \%$ of the respondents did not answer this question.

Responses below determine whether the crime rate is high, low or medium in Alice.

Figure 5: Ratings of Crime

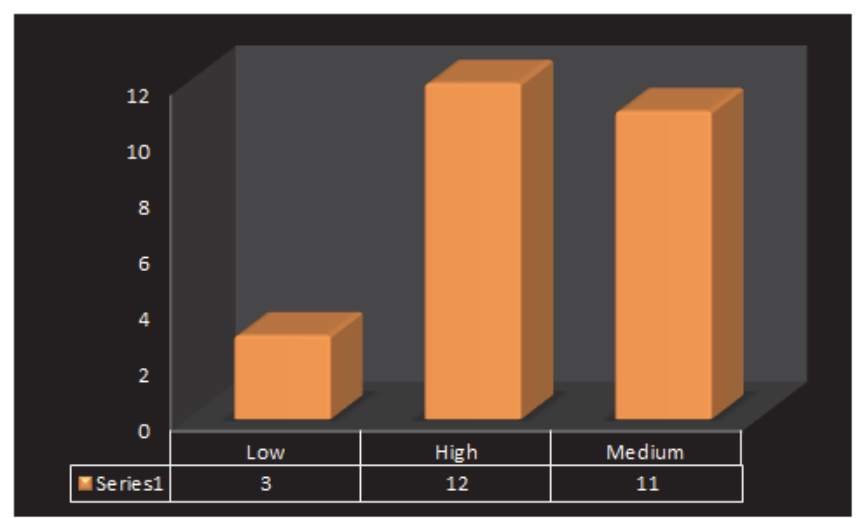

Source: Survey data (2011)

Figure 5 indicates that the majority (44.44\%) of the respondents rated the occurrence of crime in the study area as extremely high. Only 3 of the 27 respondents rated crime occurrence as low whereas one respondent did not provide an answer to this question. The high crime rate in the area indicates that unfortunately the numbers of SMEs in Alice are not able to create sufficient job opportunities to a large number of people in the area. As a result, many people are forced to commit crime.

Table 9: Burglary/ robbery at the business

\begin{tabular}{|cc|c|c|c|c|}
\hline & & Frequency & Percent & Valid Percent & Cumulative Percent \\
\hline \multirow{2}{*}{ Valid } & Yes & 12 & 44.4 & 46.2 & 46.2 \\
\multicolumn{2}{|c|}{ Missing System } & 14 & 51.9 & 53.8 & 100.0 \\
\multicolumn{2}{|c|}{ Total } & 1 & 3.7 & & \\
\hline
\end{tabular}

Source: Survey data (2011) 
Table 9 shows that there was an almost balanced split between those who indicated experiencing a burglary/ robbery or not at their business premises with the former accounting for $44.4 \%$ and the latter representing $51.9 \%$, serving as an indication that the majority of SMEs have not been robbed. One respondent did not answer this question.

Below information enables the researcher to determine whether SMEs are attempting to reduce the occurrence of HIV reduction in Alice.

Table 10: The role of SMEs in the reduction of HIV

\begin{tabular}{|cc|c|c|c|c|}
\hline & & Frequency & Percent & Valid Percent & Cumulative Percent \\
\hline \multirow{2}{*}{ Valid } & Yes & 9 & 33.3 & 34.6 & 34.6 \\
\multicolumn{2}{|c|}{ Missing System } & 17 & 63.0 & 65.4 & 100.0 \\
\multicolumn{2}{|c|}{ Total } & 1 & 3.7 & & \\
\hline
\end{tabular}

Source: Survey data (2011)

Table 10 indicates that the vast majority of the respondents did not believe that their businesses have played a major role in the reduction of HIV in the study area (63.0\%). Only 33.3\% thought differently, while $3.7 \%$ of them did not respond to this question. This result proves that small enterprises unfortunately have not begun offering HIVI AIDS prevention and treatment services to their employees and communities.

Responses below determine whether businesses are willing to sell certain goods at a cheaper price to assist indigent people.

Table 11: Selling of goods at cheaper price

\begin{tabular}{|c|c|c|c|c|}
\hline & Frequency & Percent & Valid Percent & Cumulative Percent \\
\hline \begin{tabular}{cc} 
Valid & Yes \\
Missing & System \\
\multicolumn{1}{c}{ Total }
\end{tabular} & $\begin{array}{c}26 \\
1 \\
27\end{array}$ & $\begin{array}{c}96.3 \\
3.7 \\
100.0\end{array}$ & 100.0 & 100.0 \\
\hline
\end{tabular}

Source: Survey of data (2011)

Table 11 shows that almost all respondents (96.3\%) indicated their willingness to sell certain goods at reduced prices as one way of assisting poor people. However, one respondent (3.7\%) did not provide an answer to this question. By selling certain goods at a cheaper price to poor people is one way to reduce poverty in the area.

This information below examine whether the business appoints workers by the hour in order to give more work to people.

Table 12: Appointing workers by the hour

\begin{tabular}{|lc|c|c|c|c|}
\hline & & Frequency & Percent & Valid Percent & Cumulative Percent \\
\hline \multirow{2}{*}{ Valid } & Yes & 16 & 59.3 & 61.5 & 61.5 \\
\multicolumn{2}{|c|}{ Missing System } & 10 & 37.0 & 38.5 & 100.0 \\
\multicolumn{2}{|c|}{ Total } & 1 & 3.7 & & \\
\hline
\end{tabular}

Source: Survey of data (2011)

Table 12 indicates that the majority of the respondents (59.3\%) have appointed workers by the hour to give work to more people. About 37\% do not appoint workers by the hour and 3.7\% of the respondents did not answer this question, showing that business owners actually are attempting to assist the community. 
Table 13: Cross tabulation of perception of the business in reducing unemployment rate and suggested solutions to unemployment in the area

\begin{tabular}{|c|c|c|c|c|c|c|c|}
\hline & \multicolumn{5}{|c|}{ Suggested solutions to reduce unemployment in the area } & \multirow[b]{2}{*}{ Total } \\
\hline & & $\begin{array}{c}\text { Creating } \\
\text { more jobs }\end{array}$ & $\begin{array}{l}\text { Open } \\
\text { many } \\
\text { schools }\end{array}$ & $\begin{array}{l}\text { Employ } \\
\text { uneducated } \\
\text { people }\end{array}$ & \begin{tabular}{|c|} 
Building \\
factories for \\
people
\end{tabular} & $\begin{array}{c}\text { Training } \\
\text { people }\end{array}$ & \\
\hline \multirow{2}{*}{$\begin{array}{l}\text { Has your business played an } \\
\text { important role in reducing the } \\
\text { unemployment rate in your area? }\end{array}$} & $\begin{array}{l}\text { Count } \\
\text { Agree \% within Has your business played } \\
\text { an important role in reducing the } \\
\text { unemployment rate in your area? }\end{array}$ & $\begin{array}{c}9 \\
40.9 \%\end{array}$ & $\begin{array}{c}3 \\
13.6 \%\end{array}$ & $\begin{array}{c}3 \\
13.6 \%\end{array}$ & $9.1 \%$ & $\begin{array}{c}5 \\
22.7 \%\end{array}$ & $\begin{array}{c}22 \\
100.0 \%\end{array}$ \\
\hline & $\begin{array}{l}\text { Count } \\
\text { Neutral } \% \text { within Has your business played } \\
\text { an important role in reducing the } \\
\text { unemployment rate in your area? }\end{array}$ & $33.3 \%$ & $.0 \%$ & $33.3 \%$ & $.0 \%$ & $33.3 \%$ & $100.0 \%$ \\
\hline Total & $\begin{array}{l}\text { Count } \\
\% \text { within Has your business played } \\
\text { an important role in reducing the } \\
\text { unemployment rate in your area? }\end{array}$ & $\begin{array}{c}10 \\
40.0 \%\end{array}$ & $\begin{array}{c}3 \\
12.0 \%\end{array}$ & $16.0 \%$ & $8.0 \%$ & $24.0 \%$ & $\begin{array}{c}25 \\
100.0 \%\end{array}$ \\
\hline
\end{tabular}

Source: Survey data (2011)

Table 13 above is a cross tabulation performed to assess the perception of the business having played an important role in reducing the unemployment rate and suggested solutions to unemplyment in the area. It indicates that out of 22 respondents who agreed that their businesses had played a significant role in the reduction of the unemployment rate in the study area, $40.9 \%$ thought that creating more jobs was one of the solutions to unemployment in the area. About $22.7 \%$ thought that training people was the solution, while about $27.2 \%$ thought that opening many schools and employing uneducated people was the solution to unemployment. A mean $9.1 \%$ were of the view that building factories for people would solve the problem of unemployment in the study area. Three (3) respondents were neutral, whereas two (2) did not provide answers to one or both of these questions.

Next examines the chi-square test for the business in reducing unemployment and suggested solutions to the unemployment in the area.

Table 14 : Chi-Square test for the business in reducing unemployment and suggested solutions to the unemployment in the area

\begin{tabular}{|l|c|c|c|}
\hline & Value & Df & Asymp. Sig. (2-sided) \\
\hline Pearson Chi-Square & $1.484^{\mathrm{a}}$ & 4 & .830 \\
Likelihood Ratio & 1.939 & 4 & .747 \\
Linear-by-Linear Association & .161 & 1 & .688 \\
N of Valid Cases & 25 & & \\
\hline
\end{tabular}

Source: Survey data (2011)

A chi-square test (Table 14), which was done at a significance level of $5 \%$, revealed no statistically significant association between the two variables $\left(\chi^{2}=1.48, p=0.830>0.05\right)$. This means that the proportion of respondents at each level of perception of the business having had an important role in reducing the unemployment rate in the study area was not significantly different across the suggested solutions to the problem of unemployment in the study area. The first hypothesis (null hypothesis) stated that SMEs do not contribute towards the reduction of unemployment in Alice. This is not rejected because the $p$-value $(0.830)$ is greater than the significance level $(0.05)$. It is hereby concluded that SMEs do not have a positive impact on the reduction of unemployment in Alice. 
Table 15: Cross tabulation of perception of the business in reducing poverty and whether workers are appointed by the hour to give work to more people

\begin{tabular}{|c|c|c|c|c|}
\hline & \multicolumn{2}{|c|}{$\begin{array}{l}\text { Do you appoint workers by the } \\
\text { hour to give work to more } \\
\text { people? }\end{array}$} & \multirow[t]{2}{*}{ Total } \\
\hline & & Yes & No & \\
\hline \multirow{6}{*}{$\begin{array}{l}\text { Has your business played a } \\
\text { significant role in reducing poverty } \\
\text { in the area? }\end{array}$} & Count & 12 & 8 & 20 \\
\hline & $\begin{array}{l}\text { Agree } \% \text { within Has your business played a } \\
\text { significant role in reducing poverty in } \\
\text { the area? }\end{array}$ & $60.0 \%$ & $40.0 \%$ & $100.0 \%$ \\
\hline & Count & 2 & 0 & 2 \\
\hline & $\begin{array}{l}\text { Disagree } \% \text { within Has your business played a } \\
\text { significant role in reducing poverty in } \\
\text { the area? }\end{array}$ & $100.0 \%$ & $.0 \%$ & $100.0 \%$ \\
\hline & Count & 1 & 1 & 2 \\
\hline & $\begin{array}{l}\text { Neutral } \% \text { within Has your business played a } \\
\text { significant role in reducing poverty in } \\
\text { the area? }\end{array}$ & $50.0 \%$ & $50.0 \%$ & $100.0 \%$ \\
\hline \multirow[b]{2}{*}{ Total } & Count & 15 & 9 & 24 \\
\hline & $\begin{array}{l}\% \text { within Has your business played a } \\
\text { significant role in reducing poverty in } \\
\text { the area? }\end{array}$ & $62.5 \%$ & $37.5 \%$ & $100.0 \%$ \\
\hline
\end{tabular}

Source: Survey data (2011)

Table 15 is a cross tabulation performed to assess the perception of the business having played an important role in alleviation of poverty and suggested solutions to the poverty in the area. It shows that twenty (20) respondents agreed that their businesses had played an important role in reducing poverty in the study area. Of these, $60.0 \%$ appointed workers by the hour to give work to more people whereas $40.0 \%$ did not. Two (2) respondents disagreed that their businesses had played a major role in the reduction of poverty in the area, both appointed workers by the hour to give work to more people. However, two (2) respondents were indifferent, with each of them either appointing workers by the hour to give work to more people or not. Three respondents did not provide answers to one or both of these questions.

The following section examines the chi-square test for the business in reducing poverty and whether workers are appointed to give work to more people.

Table 16: Chi-Square test for the business in reducing poverty and whether workers are appointed to give work to more people.

\begin{tabular}{|l|c|c|c|}
\hline & Value & df & Asymp. Sig. (2-sided) \\
\hline Pearson Chi-Square & $1.387^{\mathrm{a}}$ & 2 & .500 \\
Likelihood Ratio & 2.062 & 2 & .357 \\
Linear-by-Linear Association & .030 & 1 & .862 \\
N of Valid Cases & 24 & & \\
\hline
\end{tabular}

Source: Survey data (2011)

A chi-square test (Table 16) at a significance level of 5\% showed no statistically significant association between perception of business playing an important role in reducing poverty in the study area and appointment of workers by the hour to give work to more people in the study area $\left(\chi^{2}=1.39, p=0.500>0.05\right)$. This implies that the percentage of respondents at each level of perception of the business having had an important role in reducing poverty in the study are was not significantly different between those who appointed workers by the hour to give work to more people than those 
who did not. The second hypothesis (null hypothesis) of the study stated that SMEs do not contribute to the poverty allevation of Alice, hence the null hypothesis is not rejected because the the p-value (0.50) is greater than the significance level (0.05). From this test, it is concluded that SMEs do not have a significant impact on the alleviation of poverty in Alice.

Table 17: Cross tabulation of perception of business in reducing crime and rating of crime in the area

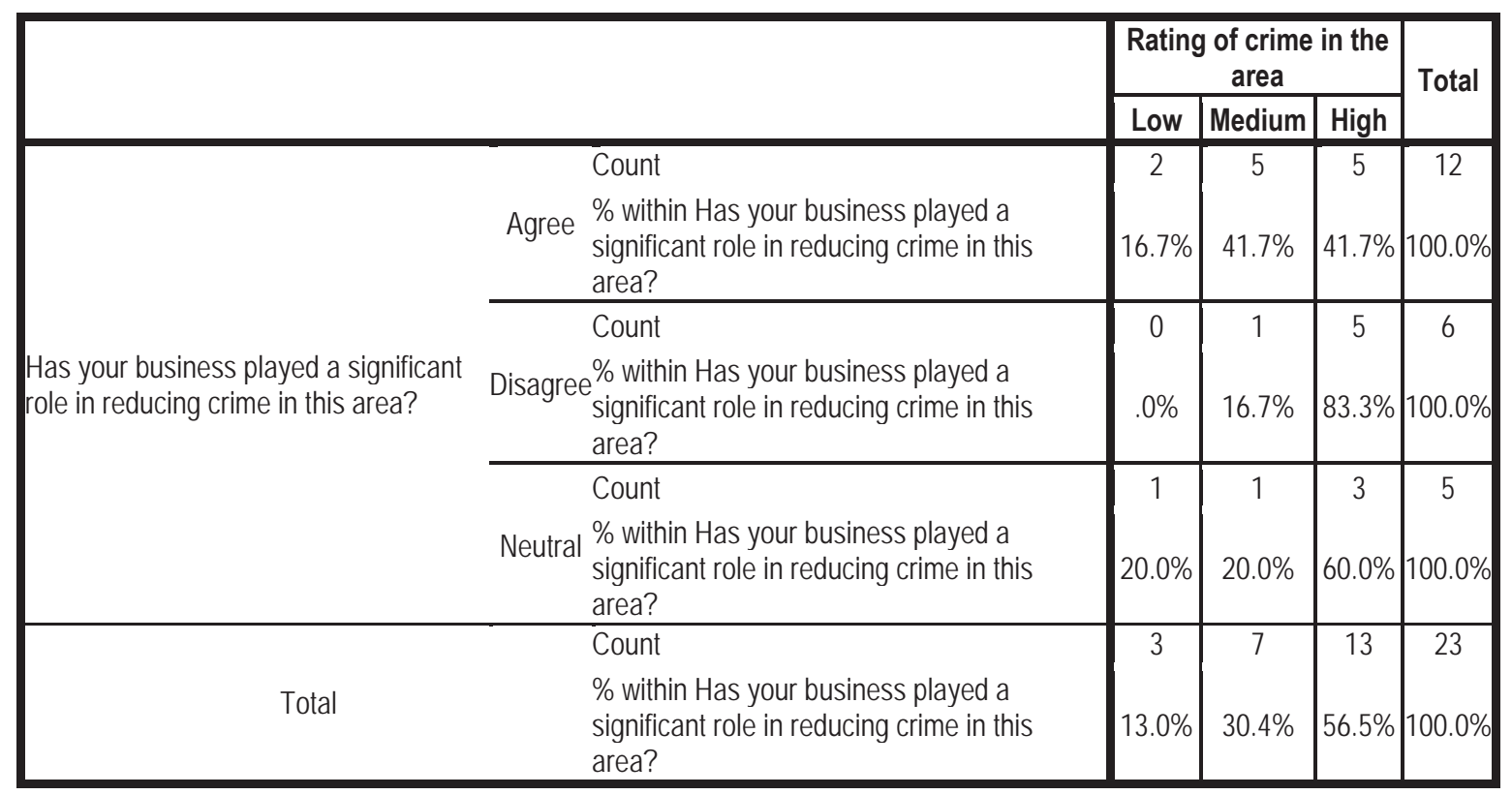

Source: Survey data (2011)

Table 17 is a cross tabulation performed to assess the perception of the businesses having played a significant role in reduction of crime and suggested solutions to the crime in the area. The results show that from a total of 12 respondents who perceived that their businesses played a major role in reducing crime in the study area, 10 respondents (83.4\%) tended to rate crime as either medium or high whereas only $16.7 \%$ indicated that cirme levels in the study area were low. Almost all respondents who disagreed that their businesses had played a major role in reducing crime in the area rated crime levels as being high (83.3\%). About $60.0 \%$ of those who remained neutral, highly rated crime prevalence in the study area, while four (4) did not provide answers to one or both of these questions.

Next on the following page examines the chi-square test for the business in reducing crime and rating of crime in the area.

Table 18: Chi-Square test for the business in reducing crime and rating of crime in the area

\begin{tabular}{|l|c|c|c|}
\hline & Value & Df & Asymp. Sig. (2-sided) \\
\hline Pearson Chi-Square & $3.381^{\mathrm{a}}$ & 4 & .496 \\
Likelihood Ratio & 4.124 & 4 & .390 \\
Linear-by-Linear Association & .530 & 1 & .467 \\
N of Valid Cases & 23 & & \\
\hline
\end{tabular}

\section{Conclusion}

Many governments around the world are turning to small business to drive economic growth and development. In many countries, small businesses are reported as the primary creator of jobs and economic stability. Currently, South Africa faces a number of social and economic problems, such as high unemployment, crime, poverty, income inequality and HIVI AIDS. The high degree of unemployment and crime has become one of the most important issues in South Africa. 
However, since the new government came into power in 1994, the government has committed itself to the promotion and growth of the SME sector to increase its contribution to socio-economic development. The primary objective of the government is to enhance the number of new ventures and to create a conducive environment to ensure the survival and development of SMEs to increase their contribution towards the socio-economic factors such as, unemployment, poverty, crime and income inequality. The government has introduced various institutions and initiatives to support the development and growth of SMEs. Small and Medium Enterprises (SMEs) are crucial for addressing the socio-economic problems in South Africa. Compared to large enterprises, SMEs are considered as a driving force in creating jobs opportunities, poverty alleviation and income generation, particularly for disadvantaged groups such as low level skills and education, women as well as for the handicapped (Sinxoto, 2007:22).

In South Africa, the importance of SMEs is widely recognized as a tool for economic growth, job creation and poverty alleviation. SMEs not only contribute significantly to improved living standards, employment generation and poverty alleviation, but also bring about substantial domestic or local capital formation and achieve high levels of productivity and capability. However, small businesses still face numerous challenges and constraints. These constraints prohibit SMEs from executing their responsibilities for job creation, poverty alleviation and sites of innovations. These constraints include the lack of finance, poor management capabilities, lack of access to markets, lack of appropriate technology, high crime rate, lack of education and management training and lack of adequate advice and information. In view of the challenges facing SMEs in South Africa, a large number of institutions were established by the Small Business Development Policy, namely Khula and SEDA. The objective of these SME support institutions is to help small businesses to increase their contribution towards socio-economic factors, such as unemployment, poverty and income inequality.

The primary objective of this research study was to investigate the effect of SMEs in the socio-economic development of Alice. The research, based on the objective of the study, showed that SMEs are not playing a crucial role in the socio-economic development of Alice. The first hypothesis stated that SMEs are not playing a significant role in the reduction of unemployment rate in Alice. The second hypothesis stated that SMEs are not playing a crucial role in the alleviation poverty of Alice. The third hypothesis also stated that SMEs do not contribute an important role in the reduction of crime in Alice. The following section, based on the research findings, provides recommendations, areas of for further research and the final conclusion.

\section{Recommendations}

The finding of this study suggests that SMEs are not playing a crucial role towards the socio-economic development of Alice. In view to increase the contribution of SMEs in the socio-economic development of Alice, it is strongly recommended that support programmes and institutions to the SMEs should be enhanced. Institutional support to SMEs, such as Khula, DTI or SEDA should speedily be established in both rural and urban areas and these institutions should be targeted to finding opportunities for SMEs to grow and flourish.

The government and other main role players should give more attention to the SME sector in order to address the challenges of the growing high unemployment rate in the country, should attempt to reduce the poverty levels, crime reduction, enhance standard of living and stimulate economic growth and development. It is also important to have a clear policy and strategy towards the development and growth of SME and also commitment by the government, civil society and business people is necessary increasing the success of the SMEs shall ensure the survival of SMEs and should be able to enhance their contribution towards the socio-economic status of the poor people.

Commercial banks and other financial institutions should be expanded in both rural and urban areas in ensuring that SMEs obtain access to funding. Lack of finance is one of the most prominent constraints to the success and development of SMEs in order to enhance their contribution in the socio-economic development. Increasing the profits of SMEs should ensure the survival of the SMEs and yield to increase contribution the upliftment of the socio-economic status of the people who would have otherwise been unemployed, destitute and poor.

To increase the contribution of SMEs towards the socio-economic problems of Alice, the government and other role players should have to commit to create a proper legal environment for entrepreneurs and provide effective entrepreneurial education and relevant training and assistance. The government should increase its efforts in creating a legal environment which provides SMEs to flourish and blossom. An environment should attempt to provide opportunities and sufficiently to attract investors as well as entrepreneurs including school leavers to be motivated enough to opt to be employers instead of looking for paid jobs.

As evidence from industrialized countries indicate that entrepreneurship education and training at school level play a significant role in the contribution to the socio-economic development. Lack of entrepreneurs is one the greatest 
challenges hampering the socio-economic development in South Africa. South Africa is characterised by low entrepreneur's spirit. The researcher also found that most of SME managers/ owners do not have qualification or even grade 12. Therefore, entrepreneurship education must be provided as a subject in primary school. It should be realised that better entrepreneurship education can play a significant role to job creation and ultimately to poverty alleviation.

\section{Acknowledgements}

We would like to thank God for His daily protection and His support. We would not have been able to complete this project without His support and guidance. Many thanks go to Prof. Adu for his assistance and guidance throughout the period to complete the paper. His support has been so immense and his suggestions played a crucial role in shaping the paper.

We would like to express our appreciation to all the respondents who have participated in the study for their time and valuable contribution without which it was almost impossible to see this paper to the completion point.

Lastly but by no means the least, we would like to thank the University of Fort Hare. This research would not be possible without their funding.

\section{References}

Central Statistics Service (CSS), (2002). The Contribution of Small and Micro- Enterprises to the Economy of the Country: A survey of Non-VAT-registered businesses in South Africa. Statistics.

Department of Trade and Industry, (1995). National Strategy for the Development and Promotion of Small Business in South Africa. Pretoria: Government Printer, Directorate of Communications. Government Notice 213.

Ferreira, E.J. (2007). An analysis of Business Interventions and their Effect on the Perceived Success of South African SMEs. Pretoria: University of South Africa.

Glen, C.J. (2000). "How Does Financial Distress Affect Small Firm's Financial Structure?" Small Business Economics 26(4):377-391, May.

Jones, O. \& Tilley, F. (2003). Competitive Advantage in SME. Organising for Innovation and Change. San Francisco: Wiley and Sons P. Kroon, J. (2000). Entrepreneurship Start Your Own Business. Cape Town: CTP Book Printers.

Ligthelm, A.A. \& Cant, M.C. (2002). Business Success Factors of SMEs in Gauteng. Pretoria: University of South Africa.

National Small Business Act, No 102, (1996). Government Gazette. 377, 17612 [On-line]. Available: http://www.info.gov.za/gazete/acts/ 2003/a26-03.pdf> [Accessed 10 June 2014].

Naude, W.A. \& Havenga, J.D. (2004). An overview of African Entrepreneurship and Small Business Research. Journal of Small Business and Entrepreneurship volume 18, No. 1:101-12.

Nieman, G. (2006). Small Business Management. Pretoria: Van Schaik.

Nieuwenhuizen, C. \& Groenewald, D. (2004). Key Issues for Improvement of Entrepreneurial Activity in South Africa. UNISA. SAIMS Conference. September 26-29.

Nieman, G. Hough, J. and Nieuwenhuizen, C. (2003). Entrepreneurship: A South African perspective. Pretoria: Van Schaik.

Onugu, B.A.N. (2005). Small and Medium Enterprises (SMEs) in Nigeria: Problems and prospects. Lagos: St. Clements University.

Petrus, H.G. (2009). An Investigation into Causes of Success and Failure in Small Businesses within the Department of Social Development in the Eastern Cape: Rhodes University.

Sinxoto, N.B. (2007). The Role of SMEs in the Socio-Economic Development of Buffalo City. South Africa: Nelson Mandela Metropolitan University.

Snower, D.J. \& De La Dehesa, G. (1997). Unemployment Policy: Government Options for the Labour Market. London: Cambridge University press.

Statistics of South Africa. 2010: Unemployment rate [On-line]. Available: http://mg.co.za/article/2010-05-04-stats-south-africaunemployment-rate-increases. [Accessed: 10 July 2014].

Sunter, C. (2000). The Entrepreneurs field book. Upper Saddle River, NJ: Prentice Hall.

United States of America Small Business Administration, (2006). Small Business Act [On- line]. Available: http://www.sba.gov/ reguilations/abaact.pdf. [Accessed: 20 June 2014].

World Bank Report, (2005). An Assessment of the Investment Climate in South Africa [On-line]. Available: http://www1.worldbank.org/ rped/documents/ICA008.pdf. [Accessed 10 June 2014].

Zindiye, S. (2008). An Empirical Investigation into the Factors Affecting the Performance of Small and Medium Enterprises in the Manufacturing Sector of Harare, Zimbabwe: University of Fort Hare.

Zwane, T.T. (2009). The Impact of Regulation on Small Businesses in the Republic of South Africa: University of Johannesburg. 